\title{
МОРФОЛОГІЧНІ ЗМІНИ ПРИ СИНДРОМІ ДІАБЕТИЧНОЇ СТОПИ
}

\author{
Р. І. Сидорчук, О. Й. Хомко, В. Б. Рева, О. І. Полянський, Л. П. Сидорчук, А. І. Попович \\ Буковинський державний медичний університет, м. Чернівці
}

\section{MORPHOLOGICAL CHANGES IN SYNDROME OF DIABETIC FOOT}

\author{
R. I. Sydorchuk, O. J. Khomko, V. B. Reva, O. I. Polyanskyi, L. P. Sydorchuk, A. I. Popovych \\ Bukovyna State Medical University, Chernivtsi
}

\section{Реферат}

Вивчено динаміку локальних морфологічних змін при синдромі діабетичної стопи (СДС) у 215 хворих за умови адекватного місцевого лікування за розробленими стандартами. За даними гістологічних досліджень, відзначали зменшення набряку, клітинної інфільтрації, мікроциркуляторних розладів в крайовій зоні рани в динаміці лікування. Через 1 тиж від початку лікування у біоптатах виявляли молоду грануляційну тканину з великою кількістю петель судин, орієнтованих перпендикулярно рановій поверхні, i численних тяжів фібробластів. Через 2 тиж спостерігали активну епітелізацію ранового дефекту в декілька шарів. 3 боку збереженої шкіри наповзав пласт, що вкривав ранову поверхню.

Ключові слова: синдром діабетичної стопи; хронічна рана; морфологічні зміни.

Abstract

Dynamics of local morphological changes in the diabetic foot syndrome was studied in 215 patients while achieving adequate local treatment in accordance to the standards elaborated. The histological investigations data witness reduction of oedema, cellular infiltration, microcirculatory disorders in marginal zone of the wound in the treatment dynamics. In one week from the treatment beginning young granulation tissue with big quantity of vascular loops, oriented perpendicularly towards the wound surface, and multiple cravings of fibroblasts were revealed. In two weeks an active epithelization of the wound defect in several layers was observed. From the side of the skin preserved a layer have crawled, covering the wound surface.

Keywords: syndrome of diabetic foot; chronic wound; morphological changes.

Синдром діабетичної стопи (СДС) $€$ однією 3 найскладніших та актуальних проблем хірургії [1 - 3]. Лікування таких хворих $€$ вкрай складним завданням, особливо при обтяженні загального стану хворих метаболічними розладами, у тому числі внаслідок цукрового діабету, порушення гемоциркуляції, впливу інших чинників, що пригнічують регенераторні та репаративні процеси, сприяють інфікуванню патологічних вогнищ, у тому числі збудниками 3 кишечнику [4 - 6]. Навіть найбільш активне місцеве лікування хворих $з$ приводу СДС неефективне, якщо воно не поєднується з технологіями, що сприяють очищенню гнійної рани та створюють сприятливі умови для регенераторних процесів [7, 8]. Водночас, різні аспекти патогенезу та морфології захворювання недостатньо вивчені та потребують уточнення.

Метою дослідження $є$ вивчення морфологічних змін при СДС.

\section{МАТЕРІАЛИ I МЕТОДИ ДОСЛІДЖЕННЯ}

Об'єктом дослідження були біоптати крайової зони ран шкіри при гнійно-некротичних процесах м'яких тканин у хворих на цукровий діабет, ускладнений СДС. Проведене комплексне патоморфологічне дослідження біопсійного матеріалу у 215 хворих, яким проведене хірургічне лікування з приводу СДС за рекомендаціями European Association for Study of Diabetes та протоколами, затвердженими МО3 України. Дотримані вимоги біоетики (GCP), всі хворі дали поінформовану згоду на участь у дослідженні. Біоптати країв рани досліджували після госпіталізації хворого, первинного оперативного втручання, а також на 3, 6, 9-ту та 15-ту добу лікування. Для оцінки динаміки перебігу ранового процесу в усіх хворих визначали ступінь зменшення площі ранової поверхні та утворення нової грануляційної тканини, проводили патоморфологічний моніторинг перебігу ранового процесу. Гістологічні зрізи вивчали, аналізували і фотографували з використанням системи аналізу зображень на базі комп'ютерної системи, що включала світловий мікроскоп Olympus CX-21 і цифрову камеру Olympus C450. Застосований комплекс сучасних гістометричних досліджень [9]. Обчислювали показники об'ємної щільності необернено ушкоджених тканин, набрякової рідини, судинно-капілярного русла, лейкоцитарної інфільтрації волокнистої, епітеліальної, м'язової і жирової тканин. Виміри проводили за допомогою комп'ютерної системи аналізу зображень Image Tools 2.1.2. Статистична обробка результатів здійснена за методами варіаційної статистики з використанням програмного пакета Statistica 7.0 в операційному середовищі Windows 7 (SP3).

\section{РЕЗУЛЬТАТИ \\ ТА ÏХ ОБГОВОРЕННЯ}

На тлі некротичних змін виявлені елементи грануляційної тканини у вигляді коротких тонких тяжів проліферуючих фібробластів веретеноподібної форми, що супроводжувалися капілярами; у 61 (28,4\%) хворого ці зміни були відсутні. На відстані 0,1 - 0,3 мм від країв рани спостерігали ознаки регенерації епідермісу у вигляді невеликих тонких пластів новоутворених кератиноцитів. За даними гістологічних досліджень відзначали зменшення набря- 
ку, клітинної інфільтрації, мікроциркуляторних розладів в крайовій зоні рани в динаміці лікування. На 6ту добу лікування у біоптатах виявлена молода грануляційна тканина 3 великою кількістю петель судин, орієнтованих перпендикулярно рановій поверхні, і численних тяжів фібробластів (рис. 1). Тонкостінні судини розташовані рівномірно по всій грануляційній тканині, практично однакового діаметра. Судинна мережа займала $(16,6 \pm 1,5) \%$ регенерату. Серед фібробластів виявляли клітини 3 мітозами. Набряк значно зменшився, інтенсивної лейкоцитарної інфільтрації регенерату не спостерігали. Характерною особливістю було виявлення в грануляційній тканині і в дермі прилеглої інтактної шкіри великої кількості опасистих клітин.

На 15-ту добу спостерігали активну епітелізацію ранового дефекту (2 - 4 шари). 3 боку збереженої шкіри

\section{REFERENCES}

1. Polovyi VP, Sydorchuk RI, Shaprynskyi VO, redaktory. Hniini protsesy m'iakykh tkanyn: etiolohiia, patohenez, likuvannia: monohrafiia. Chernivtsi: Meduniversytet; 2013. 220 s. [In Ukrainian].

2. Fomin PD, Zhuchenko OP, Zheliba MD. Profilaktyka ta likuvannia hniino-zapalnykh uskladnen pisliaoperatsiinykh laparotomnykh ran v urhentnii khirurhii: monohrafiia. Zhytomyr: ZhDU im. I. Franka; 2009. 196 c. [In Ukrainian].

3. Puri V, Venkateshwaran N, Khare N. Trophic ulcers. Practical management guidelines. Br J Dermatology. 2012;45:340-51.

4. Kondratenko PG, Sobolev VV. Khirurgicheskaya infektsiya: prakticheskoe rukovodstvo. Donetsk: Novyi svit; 2007. 512 c. [In Russian].

5. Sydorchuk RI, Fundiur VD, Kulachek VF. Bakterialna translokatsiia pry hostromu perytoniti. Shpytalna khirurhiia. 2001;1:105-8. [In Ukrainian].
6. Sydorchuk LP. Amosova KM. Influence of pharmacogenetically determined treatment on parameters of peripheral hemodynamics in patients with arterial hypertension. New Armenian Med J. 2011;5(2):35-43.

7. Fonder MA, Lazarus GS, Mamelak AJ, et al. Treating the chronic wound: A practical approach to the care of nonhealing wounds and wound care dressings. J Am Acad Dermatol. 2008;58(2):185-206.

8. Skorkowska-Telichowska K, Czemplik M, Kulma A, Szopa J. The local treatment and available dressings designed for chronic wounds. Ibid. 2011;6:1-10.

9. Sydorchuk RI. Laser polarimetry of conjunctive biotissue. Proceedings of SPIE (Coherent Optics of ordered and random media II). 2001;4705:194-202. 